\title{
Zabytkowa architektura drewniana jako element zachowania walorów historycznych miast na Podlasiu
}

\author{
Aleksander Owerczuk \\ Pracowania Historii Architektury i Konserwacji Zabytków, Wydziat Architektury, \\ Politechnika Białostocka, e-mail: a.owerczuk@pb.edu.pl
}

Streszczenie: Miasta ulegają ciągłym przeobrażeniom. Nowy kształt urbanistyczny i nowa zabudowa wkraczają do dzielnic historycznych miast. Zachowana zabytkowa architektura przeważnie nie zawiera spektakularnych obiektów. Natomiast jako całość jest cennym świadkiem epoki. W miasteczkach nierzadko ważną rolę odgrywa zabudowa drewniana, chociaż przeważnie zachowana w szczątkowym stanie. Na Podlasiu duże nasycenie zabudową drewnianą było charakterystyczne dla małych miast. Jednym z nich jest Bielsk Podlaski. Na jego przykładzie zostanie omówiony problem zmiany dawnego charakteru miasta, którego ważnym elementem była architektura drewniana.

Słowa kluczowe: zabytek, architektura drewniana, miejska architektura drewniana.

„, To zaś, co niepozorne, znacznie częściej wymaga ochrony niż to, co znaczace.

$[1$, s. 231]

Max Dvořák

\section{Wprowadzenie}

Miasta są złożonymi strukturami. Ich indywidualność ukształtowała się w procesie historycznych przemian. Najbardziej czytelnymi elementami świadczącymi o ich przeszłości są zabytki architektury. To nie tylko obiekty znaczące, przeważnie obecnie objęte urzędową ochroną, ale także skromniejsze, często wręcz niezauważalne lub nawet niechciane. Wszystkie one składają się na niepowtarzalny charakter miasta. Zauważył to już na początku XX wieku Stanisław Tomkowicz, pisząc w swojej książce „Piękność miast i jej ochrona” (1909) ,...że zabytkiem może być nie tylko ten lub ów budynek, ale cały obraz miasta, w którego skład wchodza harmonijnie przedmioty większego i mniejszego bezwzględnego znaczenia" [2, s. 58]. Natomiast na zagrożenie utraty wartości miasta jako indywidualnej całości ukształtowanej w procesie historycznego rozwoju zwrócił uwagę Max Dvořák, jeden z twórców podstaw nowoczesnej ochrony zabytków: „Czym jest opieka nad zabytkami? Niech wyjaśni to jeden przykład. Kto przed trzydziestu laty odwiedzit miasteczko N., mógł wcale niemało nacieszyć się wdzięcznym obrazem ślicznego dawnego miejsca. ... Dziś ten, kto odwiedzit miasto przed trzydziestu laty, z trudem by je rozpoznat. ... Tak więc z dawnego pięknego miasteczka nie pozostało prawie nic, ...” i dalej: „Zadaniem opieki nad zabytkami jest powstrzymywanie zniszczeń prowadzacych do takich strat i spustoszeń." $[1$, s. 229, 230] 
Przekształcanie organizmów miejskich jest procesem ciągłym. Jej skutkiem jest nieuchronne pojawianie się nowej zabudowy. Ocalałe obiekty są cennymi świadkami historii, ale obecnie przeważnie pozbawione swego historycznego otoczenia. Brak kontekstu urbanistycznego i architektonicznego w którym powstawały powoduje, że ich forma nie zawsze jest zrozumiała. Skala współczesnej zabudowy jest przeważnie większa od skali obiektów historycznych, a ich formy odmienne. Współczesna zabudowa w sąsiedztwie dawnych obiektów zabytkowych zmienia ich znaczenie w układzie przestrzennym miasta. Wprowadzenie nowej zabudowy powoduje, że także udział procentowy obiektów historycznych w zabudowie maleje. Pomniejsza to dawny charakter miasta. Znaczenia nabiera wtedy właściwe wykorzystanie wartości, które posiadają obiekty zabytkowe. Dzięki temu można ocalić chociaż część historycznego charakteru miasta. [3, s. 149]

O dawnym kształcie miasta świadczą: układ urbanistyczny, dzielnice historyczne, zespoły zabytkowe i pojedyncze obiekty. Wśród tych ostatnich prym wiodą zabytki architektury murowanej. Obiekty drewniane spotykamy przede wszystkim w środowisku wiejskim. W miastach odgrywają mniejszą, a często zupełnie marginalną rolę. Jednak stosunkowo niedawno w wielu, przede wszystkim w niedużych miastach, sytuacja jeśli chodzi o proporcje zabudowy drewnianej do murowanej wyglądała zupełnie inaczej. Architektura murowana była domeną obiektów znaczących, takich jak świątynie, budynki oficjalne czy siedziby ludzi możnych. Zabudowa skromniejsza, głównie mieszkaniowa, w przeważającym procencie była drewniana. Jednak ona też, chociaż będąc poprzez swoją skromną skalę i mało znaczącą funkcję na marginesie zainteresowań w stosunku do obiektów murowanych, współtworzyła w przeszłości, także przez ilość, niepowtarzalny charakter miasteczek, szczególnie na terenach wschodnich dawnej Rzeczypospolitej.

\section{Bielsk Podlaski - miasto „drzewiane”}

Dominujący udział budynków drewnianych w zabudowie jest charakterystyczny dla miast na Podlasiu. Wśród nich można wymienić Drohiczyn, Mielnik, Kleszczele, Brańsk. Do najważniejszych zalicza się Bielsk Podlaski. Jego zabudowa, tak jak innych miast Podlasia, była przede wszystkim drewniana. Aleksander Gwagnin w drugiej połowie XVI wieku opisał Bielsk następującymi słowami: ,,Miasto drzewiane na Podlasiu najprzedniejsze, nad rzeka Biała szerokim ciagiem przy granicy litewskiej leży” [4, s. 65] Zresztą opisując inne miasteczka Podlasia, używa także przymiotnika „drzewiane”. A więc były to miejscowości, w których dominowała zabudowa drewniana. A Ludwik Czarkowski komentując przytaczane przez niego słowa Gwagnina, odnosząc się do czasów jemu współczesnych, czyli początku XX wieku, pisze, że ,i takimi prawie pozostały po dzień dzisiejszy” [5, s. 131].

Rozwój miast na Podlasiu jest wypadkową losów tego regionu. W drugiej połowie XVII i początku XVIII wieku został zahamowany ich rozwój, a nawet nastąpił regres. W tym czasie przetoczyło się przez te tereny szereg wojen i działań zbrojnych (potop szwedzki, najazd Siedmiogrodzian, przemarsze wojsk). Doprowadziło to do dużych zniszczeń i zmniejszenia się ludności w wielu miastach Podlasia, a w konsekwencji do ich zubożenia. Także Bielsk poniósł znaczne straty. Jednak w drugiej połowie XVIII wieku, po ukresie stagnacji, miasto podnosi z upadku. Na korzystne tendencje w rozwoju miasta miało wpływ objęcie stanowiska starosty bielskiego przez Jana Klemensa Branickiego. Później stanowisko te przejęła Izabela Branicka. W tym czasie, w latach 1776-1780 zostaje wznie- 
siony nowy murowany ratusz według projektu Jan Sękowskiego ufundowany właśnie przez Izabelę Branicką przy współudziale miasta [6, s. 96]. Nowy ratusz przejął funkcję starego, drewnianego ratusza. Niedługo później w miejsce drewnianego parafialnego kościoła zostaje wzniesiona nowa murowana neoklasycystyczna świątynia według projektu znanego architekta Szymon Bogumiła Zuga. Z tego czasu pochodzi również drewniana cerkiew św. Michała Archanioła. Jej budowę rozpoczęto w 1789 roku [7, s. 131].

W okresie zaborów w latach 1796-1807 Bielsk znajduje się pod panowaniem pruskim. W tym czasie liczba domów wynosi 330. Rozpoczyna się planowy rozwój zabudowy mieszkaniowej. W tym okresie Bielsk wzbogacił się o pierwsze domy murowane [8, s. 15].

Jednak w XIX wieku nadal zabudowa mieszkaniowa praktycznie w całości była drewniana. W Bielsku w 1843 roku na ogólna liczbę 299 domów 11 było murowanych. Natomiast w 1857 roku na ogólną liczbę 316 domów murowanych było tylko 10 [5, s. 131]. Podobna sytuacja była w innych miasteczkach regionu. Tak np. w Drohiczynie w 1843 roku na 142 domy 5 było murowanych, a w 1857 na 151 domów 6 było murowanych. Dominacja zabudowy drewnianej miała miejsce w pozostałych miasteczkach regionu, a więc w Brańsku, Kleszczelach, Narwi i Mielniku (chociaż tutaj zabudowa drewniana w tym okresie sięgała prawie $10 \%$ ) [5, s. 131].

Pod koniec XIX wieku w rosnącym ludnościowo Bielsku (prawie 8 tys. mieszkańców) domów było 675, a liczbę domów murowanych w 1897 określono na zaledwie 16 [9]. W tym czasie miasto wzbogaca się także o znaczące obiekty architektury drewnianej. W 1873 roku otwarta zostaje linia kolejowa przechodząca przez Bielsk w kierunku Brześcia. Dla obsługi podróżnych zostaje wzniesiony piętrowy drewniany dworzec. Niestety, w czasie pierwszej wojny światowej dworzec zostaje zniszczony.

Zabudowa drewniana dominuje nadal w pierwszych dziesięcioleciach XX wieku. Prawie na każdym zdjęciu z początku wieku i z okresu międzywojennego widać przede wszystkim budynki drewniane [10]. Wśród nich pojawiają się obiekty znaczniejsze, będące akcentami w układzie przestrzennym miasta. Są to przede wszystkim świątynie i ratusz.

II wojna światowa przyniosła znaczne zniszczenia. W 1939 roku Bielsk krótko znajdował się pod okupacją niemiecką. Później na prawie przez dwa lata pozostawał pod okupacja sowiecką, a następnie od czerwca 1941 roku znowu pod okupacja niemiecką. W czasie wojny zniszczeniu uległa m. in. XVII-wieczna drewniana cerkiew św. Mikołaja i XVIII-wieczny budynek austerii [10, s. 19].

Po II wojnie światowej, mimo dużych zniszczeń, zachowana zabudowa drewniana nadal świadczy o dawnym charakterze architektonicznym miasta. Dopiero na przełomie lat 70-tych i 80-tych XX wieku w większej ilości stara zabudowa drewniana z XVIII i XIX wieku zaczęła znikać z krajobrazu miasta [10, s. 20]. Świadectwem dawnego charakteru miasta są drewniane cerkwie. Oprócz wspomnianej wcześniej cerkwi św. Michała Archanioła, zachowały się dwie inne drewniane cerkwie. Cerkiew Narodzenia NMP pochodzi z początku XVIII wieku. Druga pochodząca z końca XVIII została w połowie XIX wieku przeniesiona na cmentarz i pełni obecnie funkcję kaplicy cmentarnej.

Niestety przemiany, podobne do tych jakie miały miejsce w innych miasteczkach w Polsce, dotknęły także Bielsk. Nowa zabudowa, często w postaci osiedli mieszkaniowych, zaczęła wypierać tradycyjna drewnianą. W efekcie pozostało stosunkowo niewiele $\mathrm{z}$ charakteru dawnego miasta o dominującej zabudowie drewnianej. Zachowane fragmenty drewnianej zabudowy mieszkaniowej, a także pojedyncze obiekty nadal jednak można spotkać w różnych częściach miasta (fot. 1). 


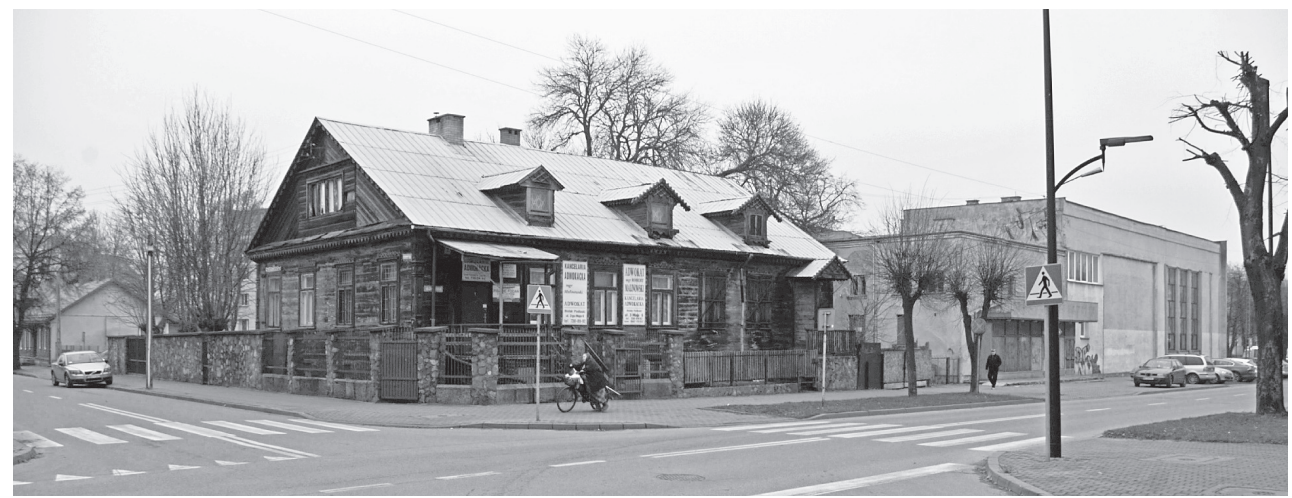

Fot. 1. Na pierwszym planie dom drewniany z drugiej połowy XIX wieku. Fot. A. Owerczuk (2017)

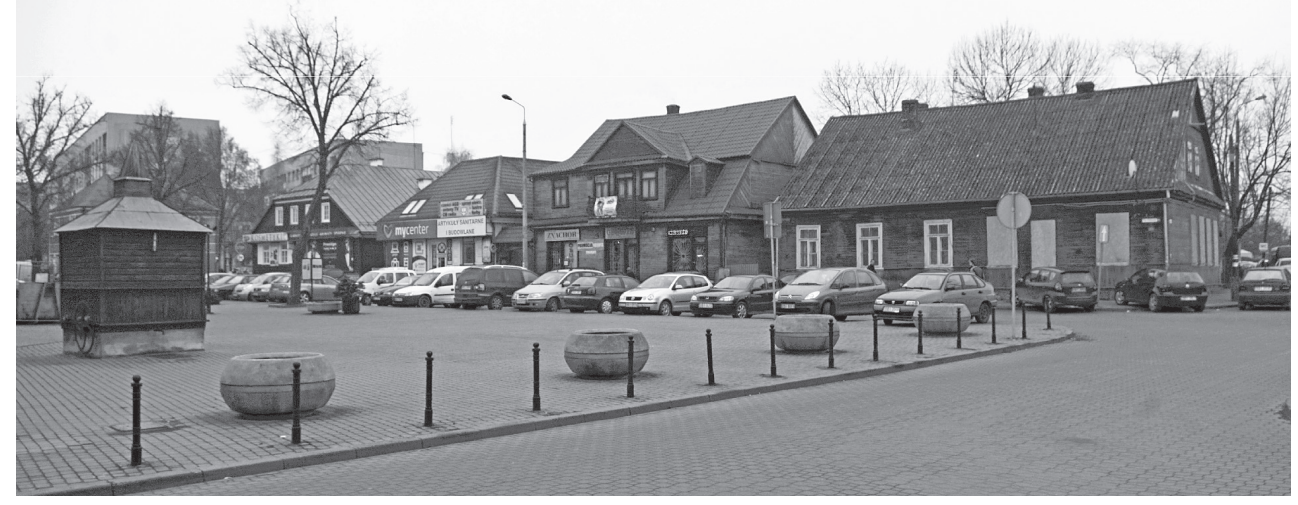

Fot. 2. Pierzeja zachodnia placu ratuszowego w Bielsku Podlaskim. Fot. A. Owerczuk (2017)

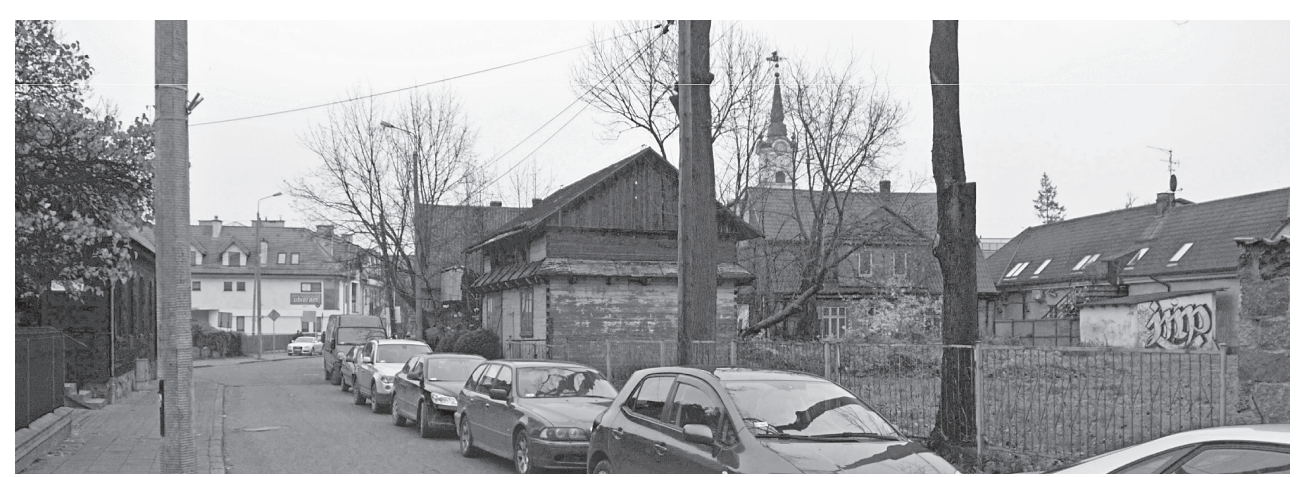

Fot. 3. Pozostałości zabudowy drewnianej w sąsiedztwie placu ratuszowego. Ponad dachami widoczna wieża ratusza. Fot. A. Owerczuk (2017)

Natomiast przy placu ratuszowym zachowała się zachodnia pierzeja o tradycyjnej zabudowie drewnianej (fot. 2), dająca wyobrażenie, jak wyglądało w większości otoczenie architektoniczne ratusza. W bliskim sąsiedztwie placu ratuszowego znajduje się kilka domów drewnianych, świadczących o charakterze zabudowy w dawnym centrum miasta (fot. 3 ). 


\section{Podsumowanie}

Problem utraty dawnego charakteru małych miast został dostrzeżony już na początku XX wieku. Praktycznie prawie wszystkie przekształcenia organizmów miejskich zmieniają dawny charakter miasta. I tak z upływem czasu maleje liczba budynków drewnianych w mieście. I mimo ochrony obiektów architektury drewnianej, los obiektów mniej znaczących, nie objętych urzędową ochroną, jest niepewny. „,Obecność architektury drewnianej to próba przetrwania $w$ zderzeniu z otaczającymi przeciwieństwami, obudowaniem, przytłoczeniem wspótczesnymi budynkami. Zmuszenie do wypracowania kompromisu dla potrzeby przeżycia." [11, s. 234] Pesymizm tej wypowiedzi jest uzasadniony. Mimo to, słuszne są starania do zachowania jak największej liczby budynków drewnianych. Niezależnie od oceny ich walorów zabytkowych, wszystkie one świadczą o niepowtarzalnym klimacie dawnych miast. I jak napisał Janusz Bogdanowski: ,,Jest szczególnie ważne, by móc zachować odmienność i oryginalność regionalizmu wsi i miasteczka, które stoją u podstaw społeczności z nimi zwiazanych. Ta bowiem tożsamość jest nieodzowna cząstka tożsamości szerzej pojmowanej, regionalnej, a także ogólnonarodowej. ” [12, s. 205]

Badania zostały zrealizowane $\mathrm{w}$ ramach pracy $\mathrm{nr} \mathrm{S} / \mathrm{WA} / 1 / 15$ i sfinansowane ze środków na naukę MNiSW.

\section{Literatura}

[1] Dvořák M. Katechizm opieki nad zabytkami. Zabytek i historia. (wybór i wstęp: Piotr Kosiewski, Jarosław Krawczyk), Oficyna Wydawnicza „Mówią wieki”, Warszawa 2007.

[2] Kłosek-Kozłowska D. Ochrona wartości kulturowych miast a urbanistyka. Oficyna Wydawnicza Politechniki Warszawskiej, Warszawa 2007, s. 58.

[3] Rymaszewski B. O przetrwanie dawnych miast. Arkady, Warszawa 1984.

[4] Zieleniewski J. Powstanie i rozwój układu przestrzennego Bielska Podlaskiego w XIV-XVIII wieku. Studia Podlaskie. t. 1, Białystok 1990.

[5] Czarkowski L. Powiat bielski w guberni grodzieńskiej. Zarys ludoznawczy, [Rocznik Towarzystwa Przyjaciół Nauk w Wilnie, 1907 r.], [w:] Bielsk Podlaski. Studia i materiały do dziejów miasta. Towarzystwo Przyjaciół Bielska Podlaskiego, Bielsk Podlaski 1999.

[6] Narolewska E. Ratusz w Bielsku Podlaskim-dzieje, przeobrażenia i konserwacja. Biuletyn Konserwatorski. Wojewódzki Oddział PSOZ w Białymstoku, Białystok 1997.

[7] Sosna G., Fionik D. Dzieje cerkwi w Bielsku Podlaskim. Białoruskie Towarzystwo Historyczne, Białystok 1995.

[8] Bielsk Podlaski. Studium historyczno-urbanistyczne do planu zagospodarowania przestrzennego miasta opracowane na zlecenie Urzędu Wojewódzkiego w Białymstoku. Wydział Kultury i sztuki, Wojewódzki Konserwator Zabytków, Warszawa 1975.

[9] Kosieradzki H. Bielsk Podlaski. Dzieje miasta. Wydawca: Miejska Rada Narodowa, Bielsk Podlaski 1987.

[10] Mazuruk K., Fionik D. Bielsk Podlaski. Miasto pogranicza. Otrhdruk, Białystok 2004.

[11 Rybka A., Kozłowska K. Zmieniający się kontekst - przyjaciel czy wróg-oblicza teraźniejszości architektury drewnianej. Architektura drewniana. Tradycja, dziedzictwo, współczesność, przyszłość. (red.: Cielątkowska R., Jankowska-Wojtowicz D.), Wydział Architektury Politechniki Gdańskiej, Gdańsk 2014.

[12] Bogdanowski J. Miasteczko i wieś a krajobrazowo-architektoniczna metoda rewaloryzacji. Wieś i miasteczko u progu zagłady. Materiały Konferencji Naukowej Stowarzyszenia Historyków sztuki Wojnowice, marzec 1988, PWN, Warszawa 1991. 


\title{
Historic wooden architecture as an element of preserving the values of historical towns in Podlasie
}

\author{
Aleksander Owerczuk \\ History of Architecture and Monument Preservation Studio, Faculty of Architecture, \\ Bialystok Univercity of Technology,e-mail: a.owerczuk@pb.edu.pl
}

\begin{abstract}
Cities are constantly changing. The new urban shape and new buildings are entering the districts of historical towns. The preserved historic architecture usually does not contain spectacular objects. However, as a whole, he is a valuable witness of the era. In towns, wooden buildings often play an important role. Often preserved in residual condition. In Podlasie, high saturation with wooden buildings was characteristic of small towns. One of them is Bielsk Podlaski. His example will discuss the problem of changing the old character of the town. Its important element was wooden architecture.
\end{abstract}

Keywords: monument, wooden architecture, urban wooden architecture. 